\title{
Analisis Pengaruh Brand Equity untuk Meningkatkan Minat Beli Ulang dan Word Of Mouth (Studi Kasus Batik Gonggong Tanjungpinang)
}

\author{
Iranita \\ Fakultas Ekonomi, Universitas Maritim Raja Ali Haji, Tanjungpinang,Kepulauan Riau, Indonesia
}

\begin{abstract}
ABSTRAK: Penelitian ini bertujuan menganalisis pengaruh Brand Equity terhadap peningkatan minat beli ulang dan Word Of Mouth (WOM). Populasi dan sampel dalam penelitian ini adalah konsumen yang telah pernah membeli batik gonggong Tanjungpinang, baik yang ada di kota Tanjungpinang, maupun konsumen yang ada di luar Tanjungpinang terutama yang telah pernah membeli batik gonggong. Penentuan sampel dalam penelitian ini menggunakan metode Accidental Sampling yaitu teknik penentuan sampel berdasarkan kebetulan bertemu dengan sejumlah kriteria yang disesuaikan dengan tujuan penelitian sehingga terpilih 60 responden yang telah memenuhi kriteria dan terlibat dalam penelitian ini dengan mengisi kuisioner yang telah disebarkan. Teknik analisis data yang digunakan dalam riset ini adalah metode analisis jalur (Path Analysis). Hasil penelitian ini menunjukkan bahwa Brand Equity (Brand Awareness dan Brand Image) terbukti berpengaruh terhadap minat beli ulang. dan Word Of Mouth (WOM) dan Hasil ini membuktikan bahwa Brand Equity (Brand Awareness dan Brand Image) memiliki peran dalam menjembatani pengaruh yang terjadi terhadap variabel minat beli ulang dan Word Of Mouth (WOM). Hasil dari penelitian ini dapat menjadi referensi bagi daerah Tanjungpinang untuk menjadikan Tanjungpinang sebagai citybranding dari batik gonggong
\end{abstract}

Kata kunci: Brand Awareness; Brand Image; Minat Beli; Word of Mouth

\begin{abstract}
This study aims to analyze the effect of Brand Equity on increasing repurchase interest and Word of Mouth (WOM). The population and sample in this study were consumers who had already bought Tanjungpinang's barking batik, both those in the city of Tanjungpinang, as well as consumers outside Tanjungpinang, especially those who had bought batik barking.

Determination of the sample in this study using the method of Accidental Sampling is a sampling technique based on chance meeting with a number of criteria that are tailored to the purpose of the study so that selected 60 respondents who have met the criteria and are involved in this study by filling out the questionnaire that has been distributed. The data analysis technique used in this research is the Path Analysis method. The results of this study indicate that Brand Equity (Brand Awareness and Brand Image) has proven to have an effect on repurchase interest and Word of Mouth and these results prove that Brand Equity (Brand Awareness and Brand Image) have a role in bridging the influence that occurs on the variable repurchase interest and Word of Mouth. The results of this study can be a reference for the Tanjungpinang area to make Tanjungpinang as a citybranding of batik barking
\end{abstract}

Keywords: Brand Awareness; Brand Image; Purchase Interest; Word of Mouth

Email Address : iranita27@gmail.com/iranita@umrah.ac.id 


\section{I.Pendahuluan}

Globalisasi dan era perdagangan bebas saat ini ditandai dengan semakin meluasnya berbagai produk dan jasa, menyebabkan persaingan bisnis yang dihadapi perusahaan-perusahaan semakin ketat. Dengan adanya pasar bebas, pemasaran semakin terbuka luas dan persaingan di dunia usaha semakin ketat, hal tersebut dapat dilihat dari masuknya produk-produk impor ke pasar Indonesia. Pemasar dituntut untuk kreatif dan inovatif agar dapat menarik perhatian konsumen dan membawa minat dari konsumen untuk membeli produk yang ditawarkan.

Dalam memasarkan suatu daerah dengan membangun citybranding, layaknya membuat marketingplan suatu produk. Dimulai dengan strategi daerah yang menghasilkan segmentasi, targeting dan positioning daerah. Dari strategi dilanjutkan dengan menetapkan taktik pemasaran dalam bentuk diferensiasi, bauran pemasaran dan proses penjualan.

Pakaian batik merupakan warisan kebudayaan Indonesia yang perlu kita pelihara, khusus generasi muda harus diimbangi dengan kreativitas dan intelegensi yang tinggi agar dapat bersaing dengan dunia global. Siput gonggong merupakan kekayaan Sumber Daya Alam (SDA) Indonesia, khususnya Kepri dalam bidang kelautan, mencerminkan kepada generasi muda untuk terus mengelola potensi alam yang ada

Kreativitas masyarakat Indonesia, khususnya Kepulauan Riau layak diacungi jempol. Karena bisa memadukan dua hal yang fenomenal menjadi sesuatu yang baru dan unik. Apa itu?. Batik Gonggong! Ya menurut penulis batik gonggong sangat unik. Motif cangkang siput gonggong yang dipadukan dengan pakaian batik menjadikan ciri khas yang menarik. Penuh dengan makna implisit di balik kemasannya. Selain itu batik gonggong juga menambah khasanah kebudayaan Indonesia.

Siput laut bernama gonggong merupakan ikon khas Kota Tanjungpinang. Maka tak heran jika banyak ditemukan serba-serbi gonggong di sana, mulai dari makanan hingga gedung berbentuk gonggong. Namun, ciri khas yang tiada duanya di tempat lain adalah batik gonggong
Motifnya seperti batik pada umumnya, namun diberi tambahan motif gonggong.. Makna filosofisnya adalah bahwa gonggong merupakan makanan yang disukai oleh semua golongan masyarakat, sehingga dapat digunakan sebagai pengingat, bahwa sebagai sesama saudara tidak boleh pilih kasih dan harus saling menyayangi.

Batik gonggong bisa jadi cendera mata yang unik dan khas dari kota di tepi laut ini. Namun demikian keberadaan batik gonggong belum dikenal luas, masih banyak wisatawan yang berkunjung ke Kota Tanjungpinang tidak mengetahui adanya kain batik motif gonggong khas Kepulauan Riau. Pembelian dilakukan hanya dari mulut ke mulut, dan promosipun yang dilakukan saat ini masih kurang, sedangkan potensi industri batik gonggong yang bagus

Jika hal ini diperhatikan akan menjadikan Tanjungpinang sebagai citybranding dari batik gonggong, dan tidak kalah dengan batik dengan motif yang telah dikenal masyarakat luas. Dan penghasil batikpun bisa dikatakan tidak ada karena pengerjaan batik gonggong dilakukan di pekalongan karena pada dasarnya membatik bukan budaya Tanjungpinang.

Indikasi faktor yang mempengaruhi naik turunnya tingkat kunjungan terhadap batik gonggong Tanjungpinang disebabkan karena banyaknya batik merek lain di Kota Tanjungpinang yang mempengaruhi tingkat kunjungan. perilaku konsumen di Tanjungpinang atau konsumen yang berkunjung ke Tanjungpinang saat berbelanja tidak terlalu memperhatikan merek, sehingga konsumen membeli produk secara acak bukan karena mengejar brand yang sudah mempunyai citra yang baik di kalangan masyarakat. Konsumen memiliki persepsi bahwa kualitas produk lokal masih rendah, inilah yang menjadi minat konsumen terhadap batik gonggong berfluktuasi.

Nama dan seberapa kuat sebuah merek merupakan asset penting. Apabila dikelola dengan tepat, merek dapat meningkatkan keunggulan kompetitif. Merek yang kuat merupakan asset untuk membedakan dengan produk lain yang sejenis, sebagaimana penelitian Prasad dan Dev (2000). Konsumen dapat dengan mudah mengingat sebuah 
merek melalui symbol merek tersebut. Sebagai contoh simbol huruf "M" emas (golden arches) sebagai logo Mc Donald.

Minat sebagai dorongan, yaitu rangsangan internal yang kuat yang memotivasi tindakan, dimana dorongan ini dipengaruhi oleh stimulus dan perasaan positif akan produk dalam Mahendrayasa (2014:2). Jika rangsangan yang di lakukan kuat dan positif maka akan mendorong konsumen dan meningkatkan minat beli mereka, sebaliknya jika rangsangan atau dorongan yang di lakukan lemah dan kurang mengena perasaan konsumen maka minat beli mereka pun lemah.

Promosi dari mulut ke mulut sering dikenal juga dengan Word of Mouth (WOM). WOM tidak membutuhkan biaya yang begitu besar, namun dapat memperoleh efektivitas yang sangat besar. Didukung lagi dengan kebiasaan masyarakat Indonesia yang senang berkumpul dan bersosialisasi untuk bercerita akan hal-hal yang mereka sukai dan alami. Menurut Macintoh (2009) bahwa Word of Mouth (WOM) diakui sebagai komunikasi positif dan sangat umum dan penting untuk layanan pemasar, serta bermanfaat untuk mempertahankan pelanggan. Dengan keterbatasan pengrajin batik gonggong tidak menyurutkan hasrat dalam mengembangkan batik gonggong dimasa yang akan datang.

Sesuai dengan urain diatas, maka peneliti menganggap ini sebagai tantangan dan studi kasus yang perlu rumuskan, dijaki dan diteliti secara mendalam untuk menyusun dan menemukan model, sehingga peneliti tertarik meneliti dengan judul "Analisis Pengaruh Brand Equity Untuk Meningkatkan Minat Beli Ulang Konsumen Dan Word Of Mouth (Studi Kasus Batik Gonggong Tanjungpinang)

\section{Tujuan Penelitian}

Dengan demikian, tujuan penelitian ini adalah:

1. Untuk mengetahui dan menganalisis pengaruh Brand Awareness Batik Gonggong terhadap Word of Mouth (WOM) melalui Peningkatan Minat Beli Ulang Batik Gonggong

2. Untuk mengetahui dan menganalisis pengaruh Brand Image Batik Gonggong terhadap Word of Mouth (WOM) melalui Peningkatan Minat Beli Ulang Batik Gonggong

3. Untuk mengetahui dan menganalisis pengaruh pengaruh Brand Awareness Batik Gonggong terhadap peningkatan minat beli ulang konsumen

4. Untuk mengetahui dan menganalisis pengaruh Brand Image Batik Gonggong terhadap peningkatan minat beli ulang konsumen

5. Untuk mengetahui dan menganalisis pengaruh Brand Awareness terhadap Word of Mouth (WOM)

6. Untuk mengetahui dan menganalisis pengaruh Brand Image terhadap Word of Mouth (WOM)

7. Untuk mengetahui dan menganalisis peningkatan Minat Beli Ulang Batik Gonggong terhadap Word of Mouth (WOM)

\section{Pengertian Minat Beli Ulang}

Minat beli diperoleh dari suatu proses belajar dan proses pemikiran yang membentuk suatu persepsi. Minat beli ini menciptakan suatu motivasi yang terus terekam dalam benaknya dan menjadi suatu keinginan yang sangat kuat yang pada akhirnya ketika seorang konsumen harus memenuhi kebutuhannya akan mengaktualisasikan apa yang ada didalam benaknya itu. Menurut Kotler dan Keller (2013), minat konsumen adalah seberapa besar kemungkinan konsumen membeli suatu merek atau seberapa besar kemungkinan konsumen untuk berpindah dari satu merek ke merek lainnya. Schiffman dan Kanuk dalam Febiana (2014:3) menyatakan bahwa minat merupakan salah satu aspek psikologis yang memiliki pengaruh cukup besar terhadap sikap perilaku. Penilaian konsumen terhadap produk tergantung pada pengetahuannya akan informasi tentang fungsi sebenarnya dari produk tersebut, dengan demikian konsumen yang berminat untuk melakukan pembelian suatu produk dipengaruhi oleh informasi yang diterima.

Minat beli ulang (repurchase intention) merupakan suatu komitmen konsumen yang terbentuk setelah konsumen melakukan pembelian suatu produk atau jasa. Komitmen ini timbul karena kesan positif konsumen terhadap merek, dan merasa puas terhadap pembelian tersebut (Hicks et al, 2005). Bucher (2005) berpendapat bahwa niat 
konsumen untuk membeli ulang adalah salah satu ukuran dari keberhasilan dari suatu perusahaan.

Menurut Hellier et al (2003) minat beli ulang merupakan keputusan konsumen untuk melakukan pembelian kembali suatu produk atau jasa berdasarkan apa yang telah diperoleh dari perusahaan yang sama, melakukan pengeluaran untuk memperoleh barang dan jasa tersebut da nada kecendrungan dilakukan secara berkala.

\section{Perilaku Word Of Mouth (WOM)}

Kepuasan pelanggan mempengaruhi pilihan tujuan,konsumsi produk, layanan dan keputusan untuk melakukan Word of Mouth (WOM) dalam Ali (2010), Molinari (2008) menjelaskan kepuasan memiliki dampak positif terhadap Word of Mouth (WOM). WOM diakui sebagai komunikasi sangat umum dan layanan pemasar,serta bermanfaat untuk mempertahankan pelanggan. Dan hal itu juga terdapat dalam Macintosh (2009).

Komunikasi lisan (Word Of Mouth marketingWOM) merupakan salah satu alat yang digunakan oleh marketer dalam menjalankan kegiatan promosinya, selain bentuk promosi yang lainnya seperti iklan, publikasi dan sebagainya. Seorang konsumen yang telah memiliki pengalaman terhadap apa yang telah dikonsumsinya atau pelayanan jasa apa yang telah dirasakannya, biasanya tidak akan sungkan untuk menyampaikan kepuasannya atau pengalamannya akan pemakaian produk atau jasa tersebut kepada orang lain. Atau dengan kata lain melakukan promosi dalam bentuk Word Of Mouth (promosi dari mulut ke mulut). (Erida, 2009).

Selain itu sebagaimana yang dikemukakan oleh Kotler \& Keller (2013) bahwa Word of Mouth Communication (WOM) atau komunikasi dari mulut ke mulut merupakan proses komunikasi yang berupa pemberian rekomendasi baik secara individu maupun kelompok terhadap suatu produk atau jasa yang bertujuan untuk memberikan informasi secara personal.

\section{Ekuitas Merek (Brand Equty)}

Kotler dan Keller (2013) mengatakan bahwa Ekuitas merek (Brand Equity) berasal dari konsumen, sehingga seringkali disebut sebagai Customer-based brand equity (CBBE). CBBE muncul ketika konsumen memiliki tingkat kesadaran dan keakraban yang tinggi dengan sebuah brand, dan memiliki asosoasi yang kuat dan unik terhadap brand tersebut dlama pikirannya. Ada dua sumber dari CBBE yaitu:

\section{Brand Awareness}

Brand awareness terdiri dari brand recognition dan brand recall performance. Brand recognition adalah kemampuan konsumen untuk mengenali sebuah merek sebelum diberikan penjelasan

Brand recall performance adalah kemampuan konsumen untuk memilih brand dari ingatannya ketika diberikan kategori produk atau kebutuhan yang dipenuhi oleh kategori produk tersebut.

\section{Brand Image}

- Asosiasi brand yang kuat (Strength of Brand Association)

Semakin dalam seseorang berpikir tentang informasi produk dan menghubungkannya dengan pengetahun tentang brand tersebut, maka semakin kuat asosiasi brand yang terjadi.

- Asosiasi brand yang menguntungkan (Favourability of Brand Association)

Asosiasi yang menguntungkan bagi sebuah brand adalah asosiasi diinginkan oleh konsumen (desirability) dan disampaikan oleh produk (deliverability)

Desirability tergantung pada faktor, dan Deliverability juga tergantung pada tiga faktor, yaitu kemampuan sebenarnya atau kemampuan potensial dari produk, kemungkinan menyampaikan saat ini atau di masa yang akan datang, Asosiasi brand yang unik (Uniqueness of Brand Assciation)

Penelitian ini dilakukan untuk menguji ada atau tidaknya pengaruh Brand Equity terhadap peningkatan minat beli ulang dan Word of Mouth (Studi Kasus batik Gonggong Tanjungpinang).

Adapun kerangka pemikiran tersebut dapat digambarkan sebagai berikut: 


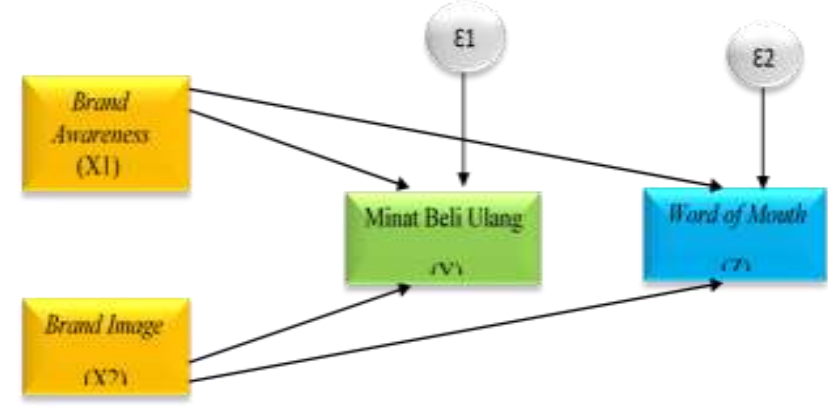

Gambar 2. Kerangka Pemikiran

\section{Hipotesis}

Berdasarkan perumusan masalah dan kerangka pemikiran di atas, maka hipotesis dalam penelitian ini dapat dirumuskan sebagai berikut:

(a) Hipotesis Pertama

Brand Awareness Batik Gonggong melalui Peningkatan Minat Beli Ulang Batik Gonggong berpengaruh terhadapBWord of Mouth (WOM)

(b) Hipotesis Kedua

Brand Image Batik Gonggong melalui Peningkatan Minat Beli Ulang Batik Gonggong berpengaruh terhadap Word of Mouth (WOM)

(c) Hipotesis Ketiga

Brand Awareness Batik Gonggong berpengaruh terhadap peningkatan minat beli ulang konsumen

(d) Hipotesis Keempat

Brand Image Batik Gonggong berpengaruh terhadap peningkatan minat beli ulang konsumen

(e) Hipotesis Kelima

Brand Awareness berpengaruh terhadap Word of Mouth (WOM)

(f) Hipotesis Keenam

Brand Image berpengaruh terhadap Word of Mouth (WOM)

(g) Hipotesis Ketujuh

Peningkatan Minat Beli Ulang Batik

Gonggong berpengaruh terhadap Word of Mouth (WOM)

\section{Metode Penelitian}

\section{Desain Penelitian}

Sesuai dengan tujuan penelitian, maka penelitian ini bersifat deskriptif (Descriptive), maksudnya adalah memberikan gambaran dan mengungkapkan adanya pengaruh Brand Equity (Brand Awareness dan Brand Image) terhadap peningkatan minat beli ulang dan Word Of Mouth.

Untuk menguji hipotesis tersebut dilakukan suatu jenis penelitian yang bersifat verifikatif (Verificative), yang gunanya untuk menguji kebenaran dari suatu hipotesis yang memakai perhitungan statistika (Sugiono:2014;63). Mengingat penelitian ini bersifat deskriptif dan verifikatif, maka metode penelitian yang digunakan adalah metode descriptive survey dan explanatory survey. Explanatory survey adalah suatu metode penelitian yang berusaha untuk mencari kejelasan hubungan antara variable dalam penelitian. Tipe ini adalah causal relationship, guna menjawab Pengaruh Brand Equity (Brand Awareness dan Brand Image) terhadap peningkatan Minat beli ulang dan Word of Mouth (studi kasus batik gonggong Tanjungpinang).

\section{Populasi dan Sampel}

Unit populasi penelitian (research population) adalah konsumen yang telah pernah membeli batik gonggong Tanjungpinang, baik yang ada di kota Tanjungpinang, maupun konsumen yang ada di luar Tanjungpinang khususnya yang telah pernah mengunjungi kota Tanjungpinang.

Pengambilan sampel yang penulis lakukan adalah menggunakan Accidental Sampling yaitu teknik penentuan sampel berdasarkan kebetulan bertemu dengan responden dapat digunakan sebagai sampel, bila dipandang orang yang kebetulan ditemuinya itu cocok sebagai sumber data (Sugiono, 2014). Digunakan teknik acidental sampling tersebut adalah dengan pengertian bahwa tidak mungkin semua populasi dapat di interview, karena keterbatasan tenaga, waktu dan biaya, anggota populasi anggota populasi lainnya dianggap homogen. Homogen dalam pengertian sampel ini adalah responden yang memiliki kesamaan dalam dalam membeli batik gonggong 
Tanjungpinang. Setelah dilakukan perhitungan diperoleh sampel sebanyak 60 responden.

\section{Metode Analisis}

Untuk menjawab masalah dan mengungkap tujuan penelitian ini digunakan metode analisis deskriptif dan untuk menjawab masalah dan tujuan penelitian ketiga, keempat dan kelima digunakan metode analisis jalur (path analysis). Untuk memudahkan pengujian hipotesis digunakan perangkat lunak komputer berupa program SPSS versi 23 dan Microsoft excel versi 2013.

Dari pengujian ini nantinya dapat dilihat seberapa besar kontribusi variabel bebas dan variabel terikat. Untuk memastikan apakah ada pengaruh Brand Equity (Brand Awareness dan Brand Image) terhadap peningkatan Minta beli Konsumen dan Word of Mouth (WOM), dalam penelitian ini dijawab dan diungkapkan melalui hipotesis penelitian, dengan menggunakan alat uji statistik analisis jalur (path analysis).

\section{Hasil dan Pembahasan}

\section{Karakteristik Responden Berdasarkan Jenis Kelamin}

Berdasarkan data yang terkumpul dari 60 orang responden yang dijadikan sampel dalam penelitian ini diperoleh informasi mengenai karakteristik responden berdasarkan jenis kelamin yang dapat dijelaskan bahwa: responden berdasarkan jenis kelamin Laki-laki berjumlah 27 orang $(45 \%)$ dan berjenis kelamin Perempuan berjumlah 33 orang (55\%). Hal ini menunjukkan bahwa responden pengguna batik gonggong terbanyak adalah yang berjenis kelamin Perempuan.

\section{Karakteristik Responden Berdasarkan Usia}

Berdasarkan data yang terkumpul dari 60 orang responden yang dijadikan sampel dalam penelitian ini diperoleh informasi mengenai karakteristik responden berdasarkan usia yang dapat dijelaskan bahwa responden berdasarkan usia, dimana rentang usia < 30 tahun berjumlah 18 Orang (29\%), usia 30 - 40 tahun berjumlah 7 orang (11\%), rentang usia 40 - 50 tahun berjumlah 27 orang (44\%) dan rentang usia > 50 tahun berjumlah 10 orang (16\%). Hal ini menunjukkan bahwa responden pengguna batik gonggong terbanyak adalah yang berusia 40 50 tahun $(44 \%)$.

\section{Karakteristik Responden Berdasarkan Pekerjaan}

Berdasarkan data yang terkumpul dari 60 orang responden yang dijadikan sampel dalam penelitian ini diperoleh informasi mengenai karakteristik responden berdasarkan pekerjaan yang dapat dijelaskan bahwa responden berdasarkan pekerjaan, dimana responden yang bekerja di swasta sebanyak 8 orang (13\%), dosen berjumlah 19 orang (29\%), Pegawai Negeri Sipil (PNS) sebanyak 15 orang (23\%), Pegawai Swasta sebanyak 8 orang (12\%), mahasiswa sebanyak 8 orang (12\%), sedangkan profesi guru sebanyak 7 orang (11\%). Hal ini menunjukkan bahwa responden pengguna batik gonggong terbanyak adalah dengan profesi Dosen.

\section{Karakteristik Responden Berdasarkan Asal Informasi Tentang Batik Gonggong}

Berdasarkan data yang terkumpul dari 60 orang responden yang dijadikan sampel dalam penelitian ini diperoleh informasi mengenai karakteristik responden berdasarkan asal diketahuinya tentang batik gonggong dijelaskan bahwa responden berdasarkan asal/sumber informasi diketahuinya tentang adanya batik gonggong khas Tanjungpinang adalah informasi berasal teman sebayak 16 orang (50\%), informasi dari keluarga sebanyak 14 orang (23\%), sedangkan informasi yang diketahui dengan

sendirinya berjumlah 16 orang (27\%). Hal ini menunjukkan bahwa asal informasi responden tentang batik gonggong yang terbanyak adalah berasal dari teman. (rekan kerja)

\section{Karakteristik Responden Berdasarkan Domisili Saat Ini}

Berdasarkan data yang terkumpul dari 60 orang responden yang dijadikan sampel dalam penelitian ini diperoleh informasi mengenai karakteristik responden berdasarkan domisili saat ini dapat dijelaskan bahwa responden berdasarkan asal/sumber informasi diketahuinya tentang adanya 
batik gonggong khas Tanjungpinang dimana responden berasal dari beberapa daerah yang ada di Indonesia seperti Jakarta, Bandung, Palu, Padang, Jambi dan Pekanbaru, Malaysia, Singapura, dan lain-lain, sedangkan responden terbanyak itu berasal dari Tanjungpinang.

\section{Analisis Statistik Deskriptif}

Menurut Ghozali (2013:20) statistik deskriptif memberikan gambaran atau deskripsi suatu data yang dapat dilihat dai nilai rata-rata (mean), standar deviasi, maksimum dan minimum. Variabel yang digunakan dalam penelitian meliputi, Brand Equity (Brand Awareness (X1) dan Brand Image (X2)), Minat Beli Ulang (Y) dan Word of Mouth (Z) dapat dilihat pada tabel stastistik deskriptif dibawah ini:

Tabel 1.

\section{Hasil Uji Statistik Deskriptif}

\begin{tabular}{|l|r|r|r|r|r|}
\hline \multicolumn{7}{|c|}{ Descriptive Statistics } \\
\hline X1 & \multicolumn{1}{|c|}{ N } & Minimum & Maximum & Mean & Std. Deviation \\
X2 & 60 & 9 & 20 & 14.00 & 2.314 \\
Y & 60 & 33 & 59 & 43.50 & 7.005 \\
Z & 60 & 6 & 15 & 12.12 & 2.478 \\
Valid N (listwise) & 60 & 19 & 40 & 29.13 & 4.942 \\
\hline
\end{tabular}

Sumber, data diolah, 2019

Dari tabel di atas menjelaskan bahwa pada Variabel Brand Awareness (X1), jawaban minimum responden sebesar 9 dan maksimum 20, dengan rata-rata total jawaban 14,00 dan standar deviasi 2,314. Variabel Brand Image (X2) jawaban minimum responden sebesar 33 dan maksimum 59, dengan rata-rata total jawaban 43,50, dan standar deviasi 7,005. Variabel Minat Beli Ulang (Y) jawaban minimum responden sebesar 6 dan maksimum 15, dengan rata-rata total jawaban 12,12 dan standar deviasi 2,247. Variable Word of Mouth (Z) jawaban minimum responden sebesar 19 dan maksimum 40, dengan rata-rata total jawaban 29,13, dan standar deviasi 4,942.

\section{Hasil Uji Validitas}

Menurut Ghozali (2013;52) bahwa uji validitas digunakaan untuk mengukur sah atau valid tidaknya suatu kuesioner. Uji validitas ini dapat dilakukan dengan mengunakan korelasi antar skor butir pertanyaan dengan total skor kontruks atau variabel. Kemudian tentukan hipotesis $\mathrm{H}_{0}$ : skor butir pernyataan tidak korelasi positif dan total skor kontruks. Setelah menentukan hipotesis $\mathrm{H}_{0}$ dan $\mathrm{H}_{1}$, kemudian uji signifikan dengan membandingkan nilai $r_{\text {hitung }}$ (table corrected item-total correlation) dengan $\mathrm{r}_{\text {tabel }}$ (table product moment dengan signifikan 0,05). Uji signifikan dilakukan dengan membandingkan nilai $r$ hitung dengan $r$ tabel untuk degree of freedom $(\mathrm{df})=\mathrm{n}-2$, dimana sampel pada penelitian ini adalah 60 responden maka df nya dengan sig 0,05 adalah 0,2542 .

Hasil untuk uji validitas variabel Brand Image (X2) hasilnya bahwa dari 12 (duabelas) pernyataan di atas dinyatakan valid dan layak dijadikan instrument dalam penelitian ini dimana semua $r$ hitung semua item pernyataan lebih besar dari $r$ tabel yaitu 0,2542 .

Selanjutnya untuk hasil uji validitas variabel Minat Beli Ulang (Y) hasilnya bahwa dari 4 (empat) pernyataan di atas dinyatakan valid dan layak dijadikan instrument dalam penelitian ini dimana semua $r$ hitung semua item pernyataan lebih besar dari $r$ tabel yaitu 0,2542 .

Hasil uji validitas variabel Word Of Mouth (Z) hasilnya dapat dilihat pada tabel sebagai berikut bahwa dari 8 (delapan) pernyataan yang diajukan dinyatakan valid dan layak dijadikan instrument dalam penelitian ini dimana semua $r$ hitung semua item pernyataan lebih besar dari $r$ tabel yaitu 0,2542 .

\section{Hasil Uji Reliabilitas}

Menurut Ghozali (2013:47) Suatu kontruks atau variabel dikatakan reliabel jika memberikan nilai Cronbach's Alpha > 0,70, maka indikator yang terdapat pada suatu kuesioner dapat dikatakan reliabel. Hasil uji reliabilitas dalam penelitian untuk setiap variabel dapat dijelaskan bahwa Cronbach Alpha Brand Awareness bernilai 0,844 yang berarti $>$ 0,70. Cronbach Alpha Brand Image bernilai 0,902 yang berarti > 0,70. Cronbach Alpha Minat Beli Ulang bernilai 0,890 yang berarti $>0,70$. Sedangkan Cronbach Alpha Word of Mouth (WOM) bernilai 0,922 yang berarti $>0,60$. 


\section{Hasil Uji Asumsi Klasik Uji Normalitas}

Uji normalitas bertujuan untuk menguji apakah dalam model regresi pada variabel independen, variabel intervening dan variabel dependen nilai residual berdistribusi secara normal atau tidak. Berikut hasil pengujian dengan grafik histogram dan grafik P-Plot yang dapat dilihat pada gambar dibawah ini:

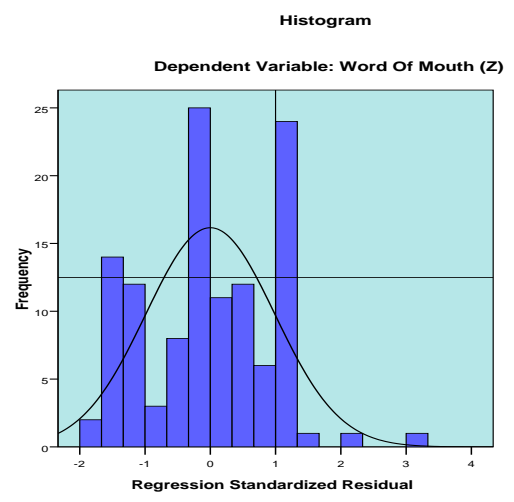

Sumber: data diolah, 2019

Gambar 3. Grafik Histogram

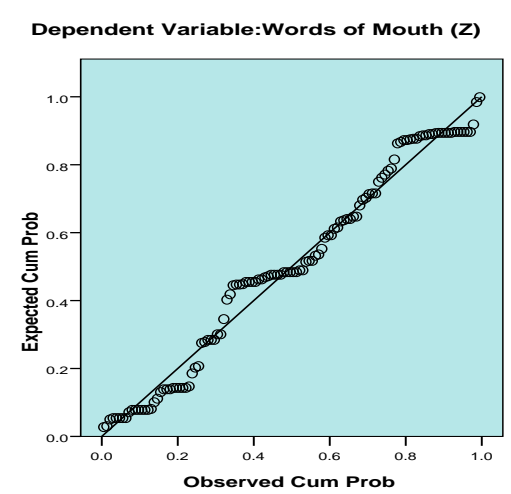

Sumber: data diolah, 2019

Gambar 4. Grafik P-Plot

Berdasarkan gambar grafik histogram di atas menunjukkan bahwa data menyebar disekitar garis diagonal dan mengikuti garis diagonal, sehingga dapat disimpulkan bahwa data yang diteliti berdistribusi normal. Pada gambar 4 diperoleh bahwa semua data berdistribusi secara normal, karena sebaran data berada disekitar garis diagonal dan mengikuti arah garis diagonal. Untuk mengetahui lebih lanjut dapat dilakukan dengan menguji uji Kalmogorov-Smirnov $(K-S)$. Jika nilai signifikan Kalmogorov-Smirnov $(K-S)$ lebih besar dari $\alpha(0,05)$

Berdasarkan tabel uji Kalmogorov-Smirnov di atas, menunjukkan nilai Asymp. Sig (2-tailed) adalah $>\alpha(0,05)$ yang dilihat dari kolom Asymp. Sig. (2-tailed) yaitu sebesar 0,798, maka dapat disimpulkan bahwa data sampel pada penelitian ini residual berdistribusi normal.

\section{Hasil Uji Multikolonieritas}

Uji multikolinearitas bertujuan untuk menguji apakah terdapat korelasi antara variabel bebas dalam model penelitian. Model yang baik adalah model yang tidak terdapat korelasi antara variabel bebas. Untuk mendeteksi ada tidaknya multikolinearitas di dalam model regresi adalah dengan melihat nilai toleransi dan Variance Inflation Factor (VIF). Apabila nilai toleransi > 0,10 dan VIF $<10$, maka dapat disimpulkan tidak ada multikolinieritas antar variabel bebas dalam model regresi. Berikut adalah nilai VIF pada model penelitian ini:

Tabel 3

Hasil Uji Multikolinieritas

\begin{tabular}{|rl|r|r|}
\hline \multicolumn{2}{|c|}{} & \multicolumn{2}{|c|}{$\begin{array}{c}\text { Collinearity } \\
\text { Statistics }\end{array}$} \\
\hline & & Tolerance & \multicolumn{1}{c|}{ VIF } \\
\hline 1 & (Constant) & & \\
& & .926 & 3.286 \\
& $\begin{array}{l}\text { Brand } \\
\text { Awareness } \\
\text { Brand Image } \\
\text { Minat Beli } \\
\text { Ulang }\end{array}$ & .386 & 4.387 \\
& .867 & 1.922 \\
\hline
\end{tabular}

a Dependent Variable: Word Of Mouth (Z) Sumber: data diolah, 2019

Berdasarkan tabel diatas, dapat dilihat hasil perhitungan menunjukkan nilai tolerance masingmasing variabel dalam model regresi memiliki nilai tolerance $>0,10$ dan hasil perhitungan nilai VIF juga menunjukkan masing-masing variabel dalam model regresi memiliki nilai VIF $<10$. Dengan 
demikian dapat disimpulkan bahwa tidak terjadi multikolinearitas antar variabel dalam model regresi.

\section{Hasil Uji Heteroskedastisitas}

Heteroskedastisitas bertujuan menguji apakah model regresi terjadi ketidaksamaan variansi dari residual satu pengamatan ke pengamatan lain. Heterokedastisitas menunjukkan penyebaran vari bel bebas. Penyebaran yang acak menunjukkan model regresi yang baik.

Dengan kata lain homokedastisitas atau tidak terjadi heterokedastisitas. Cara untuk mendeteksi ada atau tidaknya heteroskedastisitas salah satunya dengan melihat grafik scatterplot antara nilai prediksi variabel dependen yaitu: ZPRED dengan residual SRESID. Berikut hasil pengolahan menggunakan program SPSS 23:

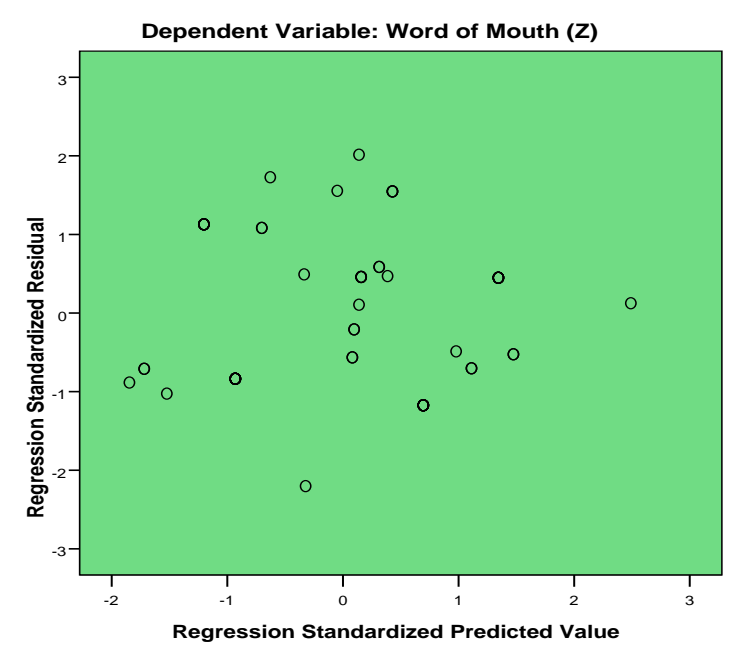

Sumber: data diolah, 2019

\section{Gambar 5.Grafik Hasil Uji Heteroskedastisitas}

Pada grafik scatterplot terlihat bahwa titik-titik menyebar secara acak serta tersebar baik di atas maupun dibawah angka nol pada sumbu Y. Hal ini dapat disimpulkan bahwa model regresi bersifat homoskedastisitas atau tidak terjadi heterokedastisitas, sehingga model ini layak dipakai untuk memprediksi loyalitas pelanggan.

\section{Pengujian Hipotesis Dengan Program SPSS 23}

Untuk menelusuri Brand Equity (Brand Awareness dan Brand Image) terhadap peningkatan Minat Beli Ulang dan Word of Mouth (WOM) dalam penelitian ini dijawab dan diungkapkan melalui hipotesis penelitian, dengan menggunakan alat uji statistik analisis jalur (path analysis). Dengan demikian diperoleh hasil dari paradigma variabel penelitian seperti berikut:

\section{Analisa Regresi Model I}

\section{Uji Signifikan Parameter Individual (Uji t)}

Uji parsial digunakan untuk menguji pengaruh Brand Awareness $\left(\mathrm{X}_{1}\right)$ dan Brand Image $\left(\mathrm{X}_{2}\right)$ terhadap Word of Mouth (Z), dalam penelitian ini uji parsial dilakukan untuk mengetahui pengaruh masing-masing variabel Brand Awareness dan Brand Image secara individual terhadap Minat Beli Ulang Batik Gonggong Tanjungpinang. Hasil analisis statistik uji t dapat dijelaskan bahwa :

1) Nilai konstanta sebensar 1,196 , artinya apabila variabel Brand Awareness, Brand Image dan Minat Beli Ulang bernilai tetap, maka Minat Beli Ulang terhadap Batik Gonggong Tanjungpinang sama dengan 1,196

2) Nilai koefisien variabel Brand Awareness adalah 0,556. Nilai Brand Awareness batik gonggong menunjukkan adanya hubungan searah antara variabel Minat Beli Ulang Batik gonggong dengan Brand Awareness, artinya jika Brand Awareness mengalami peningkatan 1 (satu) point, maka Minat Beli Ulang terhadap batik gonggong akan mengalami peningkatan sebesar 0,556 dengan asumsi bahwa variabel bebas lainnya tetap.

3) Nilai koefisien regresi variabel Brand Image menunjukkan adanya hubungan searah antara variabel Minat Beli Ulang batik gonggong dengan Brand Image, artinya jika Brand Image mengalami peningkatan 1 (satu) point, maka Minat Beli Ulang terhadap Batik gonggong akan mengalami peningkatan sebesar 0,126 dengan asumsi bahwa variabel bebas lainnya tetap.

Berdasarkan hasil uji pada tabel di atas, didapat nilai standardized coefficients beta variabel Brand Awareness $\left(\mathrm{X}_{1}\right)$ sebesar 0,289 dan nilai standardized coefficients beta variabel Brand Image $\left(\mathrm{X}_{2}\right)$ sebesar 0,369 secara parsial terhadap variabel Minat Beli Ulang Batik gonggong (Y). 
Nilai pada standardized coefficients beta Regresi model I tersebut, akan digunakan dalam perhitungan hubungan langsung dan tidak langsung variabel intervening pada penelitian ini.

\section{Hipotesis 3: diduga Brand Awareness secara partial berpengaruh signifikan terhadap Minat Beli Ulang Batik gonggong}

$\mathrm{H}_{0}$ : Brand Awareness secara parsial tidak berpengaruh signifikan terhadap Minat Beli Ulang Batik gonggong

$\mathrm{H}_{3}$ : Brand Awareness secara parsial berpengaruh signifikan terhadap kepuasan pelanggan

Variabel Brand Awareness dengan nilai sig* 0,000 dan nilai $t_{\text {hitung }} 4,016$. Ini berarti nilai sig lebih kecil dari taraf signifikan $0,05(0,000<0,05)$, dan berdasarkan perbandingan $t_{\text {hitung }}$ dengan $t_{\text {tabel }}($ $\mathrm{t}_{\text {tabel }} \alpha=0,05, \mathrm{df}=\mathrm{n}-\mathrm{k}$ maka $\mathrm{df}=60-4$ didapat $\mathrm{t}_{\text {hitung }}$ 4,016 lebih besar dari $t_{\text {tabel }} 1,6725(4,016>1,6725)$. Maka dalam hal ini $\mathrm{H}_{0}$ ditolak dan $\mathrm{H}_{1}$ diterima, sehingga Brand Awareness secara partial berpengaruh signifikan terhadap Minat Beli Ulang Batik gonggong Tanjungpinang.

Nida Fadhila, Harry Soesanto (2016) menyatakan bahwa Brand awareness diukur dengan menggunakan tiga indikator yaitu pengenalan merk,ingat terhadap merk dan dapat membedakan merk lainnya. Ketiga indikator tersebut membentuk minat beli. Sehingga mengindikasikan bahwa brand awareness memiliki pengaruh positif terhadap minat beli.

Hasil analisis menunjukkan bahwa Brand awareness berpengaruh positif terhadap Minat beli. Artinya, semakin tinggi Brand awareness terhadap suatu merk maka semakin tinggi kemungkinan terciptanya Minat beli, namun sebaliknya semakin rendah Brand awareness maka semakin rendah pula kemungkinan terciptanya Minat beli.

\section{Hipotesis 4: diduga Brand Image secara partial berpengaruh signifikan terhadap Minat Beli Ulang Batik gonggong}

$\mathrm{H}_{0}$ : Brand Image secara parsial tidak berpengaruh signifikan terhadap Minat Beli Ulang Batik gonggong

$\mathrm{H}_{4}$ : Brand Image secara parsial berpengaruh signifikan terhadap Minat Beli Ulang Batik gonggong

Variabel Brand Image dengan nilai sig* 0,000 dan nilai $t_{\text {hitung }} 3,181$. Ini berarti nilai sig lebih kecil dari taraf signifikan $0,05(0,000<0,05)$, dan berdasarkan perbandingan $t_{\text {hitung }}$ dengan $t_{\text {tabel }}($ $\mathrm{t}_{\text {tabel }} \alpha=0,05, \mathrm{df}=\mathrm{n}-\mathrm{k}$ maka $\mathrm{df}=60-4$ didapat $\mathrm{t}_{\text {hitung }}$ 4,016 lebih besar dari $t_{\text {tabel }} 1,6725(3,181>1,6725)$. Maka dalam hal ini $\mathrm{H}_{0}$ ditolak dan $\mathrm{H}_{1}$ diterima, sehingga Brand Image secara partial berpengaruh signifikan terhadap Minat Beli Ulang Batik gonggong Tanjungpinang.

Berdasarkan hasil analisis yang dilakukan oleh Mendrika (2017) menyatakan bahwa regresi brand image berpengaruh terhadap minat beli ulang.hal ini dilihat dari hasiluji hipotesis (Uji t)yaitu $6,147>1,66039$ adalah $\mathrm{H}_{0}$ ditolak dan $\mathrm{H}_{\mathrm{a}}$ diterima. pengaruh brand image ini bersifat positif signifikan dengan nilai sig. 0,000 artinya apabila brand image semakin baik, maka hal tersebut akan semakin menimbulkan atau mendorong minat beli ulang.

\section{Uji Koefisien Determinasi (Adjusted $\mathbf{R}^{\mathbf{2}}$ )}

Koefisien determinasi $\left(\mathrm{R}^{2}\right)$ bertujuan untuk mengetahui seberapa besar kemampuan variabel Brand Awareness $\left(\mathrm{X}_{1}\right)$ dan Brand Image $\left(\mathrm{X}_{2}\right)$ secara keseluruhan dalam menjelaskan variabel Minat Beli Ulang Batik Gonggong (Z), dalam penelitian ini uji koefisien determinasi dilakukan untuk mengetahui besarnya nilai Adjusted $R$ pada regresi model I. Hasil analisis koefisien determinasi dapat dilihat pada tabel dibawah ini:

Tabel 5.

\section{Hasil Uji Koefisien Determinasi (Adjusted $\mathbf{R}^{2}$ )}

Model Summary

\begin{tabular}{|l|r|r|r|r|}
\hline Model & \multicolumn{1}{|c|}{$\mathrm{R}$} & $\mathrm{R}$ Square & $\begin{array}{c}\text { Adjusted } \\
\text { R Square }\end{array}$ & $\begin{array}{r}\text { Std. Error of } \\
\text { the Estimate }\end{array}$ \\
\hline 1 & $.795^{\mathrm{a}}$ & .632 & .625 & 1.10914 \\
\hline
\end{tabular}

a. Predictors: (Constant), X2, X1

Sumber: data diolah, 2019 
Berdasarkan tabel di atas dapat dilihat bahwa hasil analisis SPSS Model Summary menunjukkan bahwa besarnya nilai Adjusted $R$ Square adalah 0,632 atau sama dengan $63,2 \%$.

\section{Analisa Regresi Model II}

Analisis regresi model II (dua) digunakan untuk mengetahui kekuatan hubungan variabel bebas (independent) terhadap variabel terikat (dependent).

\section{Uji Signifikansi Parameter Individual (Uji t)}

Uji parsial digunakan untuk menguji pengaruh Brand Awareness $\left(\mathrm{X}_{1}\right)$, Brand Image $\left(\mathrm{X}_{2}\right)$ terhadap Minat Beli Ulang Batik Gonggong (Y) dan Word of Mouth (Z) secara parsial. Uji parsial dalam penelitian ini dilakukan untuk mengetahui nilai signifikansi pengaruh masing-masing variabel Brand Awareness, Brand Image terhadap Minat Beli Ulang Batik Gonggong dan terhadap Word of Mouth. Hasil analisis statisrik uji t dapat dilihat pada tabel dibawah ini:

Tabel 6.

Uji Signifikansi Parameter Individual (Uji t)

\begin{tabular}{|c|c|c|c|c|c|c|}
\hline \multirow{2}{*}{\multicolumn{2}{|c|}{ Model }} & \multicolumn{2}{|c|}{$\begin{array}{c}\text { Unstandardized } \\
\text { Coefficients }\end{array}$} & $\begin{array}{c}\text { Standardi } \\
\text { zed } \\
\text { Coefficie } \\
\text { nts }\end{array}$ & \multirow[b]{2}{*}{$\mathrm{t}$} & \multirow[b]{2}{*}{ Sig. } \\
\hline & & B & $\begin{array}{l}\text { Std. } \\
\text { Error }\end{array}$ & Beta & & \\
\hline 1 & (Constant) & $\begin{array}{r}1.19 \\
6\end{array}$ & 2,446 & & $\begin{array}{r}1.72 \\
8\end{array}$ & ,087 \\
\hline & $\begin{array}{l}\text { Brand } \\
\text { Awarenes } \\
s(\mathrm{X} 1) \\
\end{array}$ & ,556 &, 056 & 289 & $\begin{array}{r}4,01 \\
6\end{array}$ & 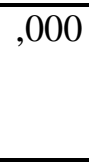 \\
\hline & $\begin{array}{l}\text { Brand } \\
\text { Image } \\
(\mathrm{X} 2)\end{array}$ &, 126 &, 055 & ,369 & $\begin{array}{r}3,18 \\
1\end{array}$ &, 000 \\
\hline
\end{tabular}

Sumber: data diolah, 2019

Berdasarkan hasil uji SPSS di atas, maka persamaan regresi yang mencerminkan variabelvariabel dalam penelitian ini adalah:

$Z=3,563+0,045 X_{1}+0,408 X_{2}+0,977 Y+e_{2}$
Dari persamaan di atas dapat dijelaskan bahwa:

1) Nilai konstanta sebesar 3,563 artinya apabila variabel Brand Awareness, Brand Image terhadap Minat Beli Ulang Batik Gonggong dan Word Of Mouth adalah sama dengan 3,563

2) Nilai koefisien regresi variabel Brand Awareness adalah 0,045. Nilai Brand Awareness menunjukkan adanya hubungan searah antara variabel Word Of Mouth dengan Brand Awareness, artinya jika Brand Awareness mengalami peningkatan 1 (satu) poin, maka Word Of Mouth akan mengalami peningkatan sebesar 0,045 dengan asumsi bahwa variabel bebas lainnya tetap.

3) Nilai koefisien regresi variabel Brand Image adalah 0,408. Nilai Brand Image menunjukkan adanya hubungan searah antara variabel Word Of Mouth dengan Brand Image, artinya jika Brand Image mengalami peningkatan 1 (satu) poin, maka Word Of Mouth akan mengalami peningkatan sebesar 0,005 dengan asumsi bahwa variabel bebas lainnya tetap.

4) Nilai koefisien regresi variabel Minat Beli Ulang Batik Gonggong adalah 0,977. Nilai Minat Beli Ulang Batik Gonggong menunjukkan adanya hubungan searah antara variabel Word Of Mouth dengan Minat Beli Ulang Ulang Batik Gonggong, artinya jika Minat Beli Ulang Batik Gonggong mengalami peningkatan 1 (satu) poin, maka Word of Mouth akan mengalami peningkatan sebesar 0,977 dengan asumsi bahwa variabel bebas lainnya tetap.

Berdasarkan hasil uji pada tabel 4.12, didapat nilai standardized coefficients beta variabel Brand Awareness $\left(\mathrm{X}_{1}\right)$ sebesar $(0,095)$, nilai standardized coefficients beta variabel Brand Image $\left(\mathrm{X}_{2}\right)$ sebesar 0,598 dan nilai standardized coefficients beta variabel Minat Beli Ulang Batik Gonggong (Y) sebesar 0,033 secara parsial terhadap variabel Word Of Mouth (Z). Nilai pada uji signifikansi regresi model II tersebut akan digunakan untuk perhitungan hubungan variabel intervening dalam penelitian ini, yang mana akan dikalikan dengan nilai standardized coefficients beta uji signifikansi parameter individual regresi 
model I pada masing masing variabel secara parsial.

\section{Hipotesis 5: diduga Brand Awareness secara partial berpengaruh signifikan terhadap Word Of Mouth}

$\mathrm{H}_{0}$ : Brand Awareness secara parsial tidak berpengaruh signifikan terhadap Word of Mouth

$\mathrm{H}_{5}$ : Brand Awareness secara parsial berpengaruh signifikan terhadap Word Of Mouth

Variabel Brand Awareness dengan nilai sig* 0,002 dan nilai $t_{\text {hitung }} 3,235$. Ini berarti nilai sig lebih kecil dari taraf signifikan 0,05 $(0,000<0,05)$, dan berdasarkan perbandingan $t_{\text {hitung }}$ dengan $t_{\text {tabel }}($ $\mathrm{t}_{\text {tabel }} \alpha=0,05, \mathrm{df}=\mathrm{n}-\mathrm{k}$ maka $\mathrm{df}=60-4$ didapat $\mathrm{t}_{\text {hitung }}$ 3,235 lebih besar dari $t_{\text {tabel }} 1,6725(3,235>1,6725)$. Maka dalam hal ini $\mathrm{H}_{0}$ ditolak dan $\mathrm{H}_{1}$ diterima, sehingga Brand Awareness secara partial berpengaruh signifikan terhadap Word Of Mouth

Hasil ini bertolak belakang dengan penelitian yang dilakukan oleh Christina (2017) yang menyatakan bahwa tidak ada pengaruh kesadaran merek (brand awareness) terhadap minat beli. Sedangkan penelitian oleh Aditya (2017) bahwa Brand equity berpengaruh positif dan signifikan terhadap niat beli konsumen produk Chitato Rasa Indomie.

Selanjutnya dari hasil penelitian Rizki (2018) dan Nida Fadhila, Harry Soesanto (2016) bahwa Brand awareness diukur dengan menggunakan tiga indikator yaitu pengenalan merk,ingat terhadap merk dan dapat membedakan merk lainnya. Ketiga indikator tersebut membentuk minat beli sehingga kesadaran merek (Brand awareness) terhadap minat pembelian ulang memiliki pengaruh positif. Artinya semakin tinggi Brand awareness maka Word Of Mouth semakin tinggi, sebaliknya jika Brand awareness rendah maka Word Of Mouth semakin rendah.

\section{Hipotesis 6: diduga Brand Image secara partial berpengaruh signifikan terhadap Word Of Mouth}

$\mathrm{H}_{0}$ : Brand Image secara parsial tidak berpengaruh signifikan terhadap Word Of Mouth

$\mathrm{H}_{6}$ : Brand Image secara parsial berpengaruh signifikan terhadap Word Of Mouth

Variabel Brand Image dengan nilai sig 0,796 dan nilai $t_{\text {hitung }} 0,259$. Ini berarti nilai sig lebih besar dari taraf signifikan $0,05(0,796>0,05)$, dan berdasarkan perbandingan $t_{\text {hitung }}$ dengan $t_{\text {tabel }}\left(t_{\text {tabel }} \alpha\right.$ $=0,05, \mathrm{df}=\mathrm{n}-\mathrm{k}$ maka $\mathrm{df}=60-4$ didapat $\mathrm{t}_{\text {hitung }} 0,259$ lebih kecil dari $t_{\text {tabel }} 1,6725(0,259<1,6725)$. Maka dalam hal ini $\mathrm{H}_{0}$ diterima dan $\mathrm{H}_{1}$ ditolak, sehingga Brand Image secara partial tidak berpengaruh signifikan terhadap Word Of Mouth.

\section{Hipotesis 7: diduga Minat Beli Ulang Batik Gonggong secara partial berpengaruh signifikan terhadap Word Of Mouth}

$\mathrm{H}_{0}$ : Minat Beli Ulang Batik Gonggong secara parsial tidak berpengaruh signifikan terhadap Word Of Mouth

$\mathrm{H}_{7}$ : Minat Beli Ulang Batik Gonggong secara parsial berpengaruh signifikan terhadap Word Of Mouth

Variabel Minat Beli Ulang Batik Gonggong dengan nilai sig 0,000 dan nilai $t_{\text {hitung }} 4,958$. Ini berarti nilai sig lebih besar dari taraf signifikan $0,05(4,958>0,05)$, dan berdasarkan perbandingan $\mathrm{t}_{\text {hitung }}$ dengan $\mathrm{t}_{\text {tabel }}\left(\mathrm{t}_{\text {tabel }} \alpha=0,05, \mathrm{df}=\mathrm{n}-\mathrm{k}\right.$ maka $\mathrm{df}=$ $60-4$ didapat $t_{\text {hitung }} 4,598$ lebih besar dari $t_{\text {tabel }}$ $1,6725(4,958<1,6725)$. Maka dalam hal ini $\mathrm{H}_{0}$ ditolak dan $\mathrm{H}_{1}$ diterima, sehingga Minat Beli Ulang Batik Gonggong secara partial berpengaruh signifikan terhadap Word Of Mouth .

Hal ini sejalan dengan penelitian yang dilakukan oleh Nurvidiana dalam Rahma dkk (2015) bahwa Word Of Mouth berpengaruh terhadap minat beli. Selain itu Pengaruh Minat Beli Ulang terhadap Word of Mouth Minat Beli Ulang berpengaruh positif terhadap Word Of Mouth. Seorang konsumen akan cenderung lebih percaya terhadap rekomendasi melalui jalur Word Of Mouth daripada metode promosi formal dikarenakan pemberi rekomendasi diyakini berbicara jujur,tulus 
dan tidak ditunggangi oleh motif tersembunyi (Andriyanto 2010),

Sejalan dengan penelitian Nida Fadhila dan Harry Soesanto (2016) menyatakan bahwa Word of mouth diukur dengan menggunakan tiga indikator yaitu merekomendasikan, membicarakan positif, dan mengajak untuk membeli. Hasil analisis menunjukkan Minat beli berpengaruh positif terhadap Word of mouth. Artinya, semakin tinggi Word of mouth terhadap suatu produk maka semakin tinggi kemungkinan terciptanya Minat beli, namun sebaliknya semakin rendah Word of mouth maka semakin rendah pula kemungkinan terciptanya Minat beli.

Hasil penelitian ini sejalan dengan penelitian yang dilakukan oleh Kumla (2013) yang menyatakan jika word of mouth mempunyai pengaruh signifikan terhadap minat beli. Selain itu Kurnia (2012) juga menyatakan word of mouth mempunyai pengaruh signifikan terhadap minat beli. Dengan demikian dapat disimpulkan informasi yang di dapat melalui aktifitas word of mouth dapat mempengaruhi timbulnya minat beli seseorang dalam melakukan aktifitas pembelian.

\section{Uji Koefisien Determinasi (Adjusted $\mathbf{R}^{\mathbf{2}}$ )}

Koefisien determinasi $\left(R^{2}\right)$ bertujuan untuk mengetahui seberapa besar kemampuan variabel Brand Awareness $\left(\mathrm{X}_{1}\right)$ dan Brand Image $\left(\mathrm{X}_{2}\right)$ secara keseluruhan dalam menjelaskan variabel Minat Beli Ulang Batik Gonggong (Y) secara keseluruhandalam menjelaskan variabel Word of Mouth, dalam penelitian ini uji koefisien determinasi dilakukan untuk mengetahui besarnya nilai Adjusted $R$ pada regresi model I. Hasil analisis koefisien determinasi dapat dilihat pada tabel dibawah ini.

Tabel 7.

\section{Hasil Uji Koefisien Determinasi (Adjusted $\mathbf{R}^{2}$ )}

Model Summary

\begin{tabular}{|l|r|r|r|r|}
\hline Model & \multicolumn{1}{|c|}{$\mathrm{R}$} & R Square & $\begin{array}{c}\text { Adjusted } \\
\text { R Square }\end{array}$ & $\begin{array}{r}\text { Std. Error of } \\
\text { the Estimate }\end{array}$ \\
\hline 1 & $.896^{\mathrm{a}}$ & .802 & .797 & 2.36461 \\
\hline
\end{tabular}

a. Predictors: (Constant), Y, X1, X2
Berdasarkan tabel di atas, dapat dilihat bahwa hasil analisis SPSS model summary menunjukkan bahwa besarnya Adjusted $R$ Square adalah 0,802 atau $80,2 \%$, ini berarti bahwa variabel Word of Mouth dapat dijelaskan oleh variabel Brand Awareness, Brand Image terhadap Minat Beli Ulang Batik Gonggong sebesar 80,2\% dan 19,8\% sisanya dijelaskan oleh variabel lain yang tidak dimasukkan dalam penelitian ini.

\section{Analisis Jalur (Path Analysis)}

Untuk membuktikan bahwa variabel Minat Beli Ulang Batik Gonggong mampu menjadi variabel yang memediasi antara variabel Brand Awareness dan Brand Image terhadap Word Of Mouth, maka akan dilakukan perhitungan pengaruh langsung atau tidak langsung antara Brand Awareness dan Brand Image.

Apabila pengaruh tidak langsung Brand Awareness dan Brand Image melalui Minat Beli Ulang Batik Gonggong lebih besar dibandingkan pengaruh secara langsung Brand Awareness dan Brand Image terhadap Word Of Mouth, maka Minat Beli Ulang Batik Gonggong bisa menjadi variabel yang memediasi antara Brand Awareness dan Brand Image terhadap Word Of Mouth. Menurut Dito (dalam Oktapriani, 2018) untuk melakukan perhitungan secara langsung dan tidak langsung dapat dilakukan dari nilai standardized coefficients regresi masing-masing variabel independen terhadap variabel dependen dan dapat dibuat analisis jalur sebagai berikut:

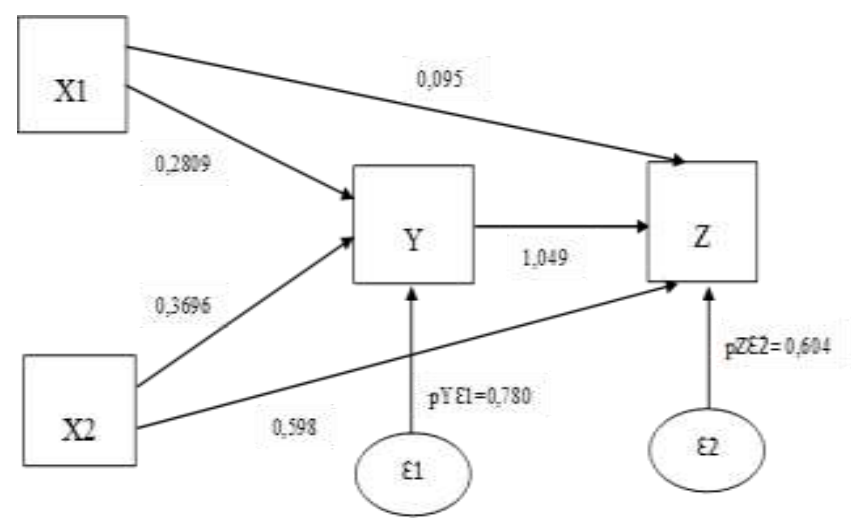

Gambar 4.11

Sumber: data diolah, 2019 


\section{Analisis Jalur (Path Analysis) Brand Awareness dan Brand Image terhadap Word of Mouth melalui Minat Beli Ulang}

Besarnya nilai error pada masing-masing pengaruh variabel independen terhadap dependen didapat melalui perhitungan sebagai berikut:

$$
\begin{aligned}
e_{1} & =\sqrt{1-\mathrm{R}^{2}} \\
& =\sqrt{1-0,625^{2}}=0,780 \\
e_{2} & =\sqrt{1-\mathrm{R}^{2}} \\
& =\sqrt{1-0,797^{2}}=0,604
\end{aligned}
$$

Dalam teori trimming (Oktapriani, 2018) pengujian validitas model riset diamati melalui perhitungan koefisien determinasi total sebagai berikut:

$$
\begin{aligned}
\mathrm{R}_{\mathrm{m}}^{2} & =1-\mathrm{P}^{2} \mathrm{e}_{1} \mathrm{P}^{2} \mathrm{e}_{2} \ldots . . \mathrm{P}^{2} \mathrm{e}_{\mathrm{p}} \\
& =1-(0,780)^{2}(0,604)^{2} \\
& =1-0,222 \\
& =0,778=77,8 \%
\end{aligned}
$$

Nilai koefisien determinasi pada teori trimming tersebut, menunjukkan bahwa 77,8\% informasi yang terdapat dalam data dapat dijelaskan oleh model, sedangkan untuk 22,2\% dijelaskan oleh eror dan variabel lain diluar model. Angka koefisien pada model ini cukup besar sehingga layak untuk dilakukan interpretasi lebih lanjut.

\section{Pengaruh Langsung dan Tidak Langsung}

(1) Pengaruh Brand Awareness terhadap Word of Mouth

- Pengaruh Langsung $\left(\mathrm{X}_{1} \mathrm{Z}\right)=0,095$

- Pengaruh tidak langsung (melalui Minat Beli Ulang) $\left(\mathrm{X}_{1} \mathrm{Y}\right)=(0,289)(1,049)=0,303$

(2) Pengaruh Brand Image Terhadap Word of Mouth

- Pengaruh Langsung $\left(\mathrm{X}_{2} \mathrm{Z}\right)=0,005$

- Pengaruh tidak langsung (melalui Minat Beli Ulang)

$$
\left(X_{2} Y\right)=(0,369)(1,049)=0,387
$$

\begin{tabular}{|c|c|c|c|c|c|}
\hline $\begin{array}{c}\text { Variabe } \\
\text { l }\end{array}$ & $\begin{array}{c}\text { Dire } \\
\text { ct }\end{array}$ & $\begin{array}{c}\text { Indire } \\
\text { ct }\end{array}$ & $\begin{array}{c}\text { Tot } \\
\text { al }\end{array}$ & $\begin{array}{c}\text { Krite } \\
\text { ria }\end{array}$ & $\begin{array}{l}\text { Kesimpu } \\
\text { lan }\end{array}$ \\
\hline $\begin{array}{l}\text { Brand } \\
\text { Awaren } \\
\text { ess }\end{array}$ & 0,095 & 0,303 & $\begin{array}{c}0,39 \\
8\end{array}$ & $\begin{array}{l}\text { Direct } \\
\text { effect } \\
< \\
\text { indere } \\
\text { ct } \\
\text { effect }\end{array}$ & $\begin{array}{l}\text { Minat } \\
\text { Beli } \\
\text { Ulang } \\
\text { Konsume } \\
\text { n sebagai } \\
\text { variabel } \\
\text { interveni } \\
\text { ng }\end{array}$ \\
\hline $\begin{array}{l}\text { Brand } \\
\text { Image }\end{array}$ & 0,005 & 0,387 & $\begin{array}{c}0,93 \\
2\end{array}$ & $\begin{array}{l}\text { Direct } \\
\text { effect } \\
< \\
\text { indere } \\
\text { ct } \\
\text { effect }\end{array}$ & $\begin{array}{l}\text { Minat } \\
\text { Beli } \\
\text { Ulang } \\
\text { Konsume } \\
\text { n sebagai } \\
\text { variabel } \\
\text { interveni } \\
\text { ng }\end{array}$ \\
\hline
\end{tabular}

Berdasarkan perhitungan di atas, amak pengaruh tidak langsung lebih besar dari pada pengaruh langsung, maka dapat disimpulkan bahwa hubungan yang sebenarnya adalah tidak langsung atau variabel mediasi.

Tabel 8.

Hasil Analisis Pengaruh Langsung dan Tidak Langsung

Sumber: data diolah, 2019

Berdasarkan uraian tabel di atas, maka dapat disimpulkan bahwa $\mathbf{H}_{\mathbf{1}}$ dan $\mathbf{H}_{\mathbf{2}}$ diterima karena pengaruh secara tidak langsung melalui Minat Beli Ulang konsumen lebih besar dibanding pengaruh secara langsung terhadap Word of Mouth (WOM)

Hipotesis 1: Diduga Brand Awareness berpengaruh signifikan terhadap Word of Mouth (WOM) melalui Minat Beli Ulang

$\mathrm{H}_{0}$ : Brand Awareness tidak berpengaruh signifikan terhadap Word of Mouth (WOM) melalui Minat Beli Ulang

$\mathrm{H}_{1}$ : Brand Awareness berpengaruh signifikan terhadap Word of Mouth (WOM) melalui Minat Beli Ulang

Berdasarkan tabel 8 mengenai hasil analisis pengaruh langsung dan tidak langsung, maka dapat disimpulkan bahwa hipotesis $1\left(\mathrm{H}_{1}\right)$ dapat diterima 
karena kekuatan hubungan pengaruh secara tidak langsung Brand Awareness terhadap Word of Mouth (WOM) melalui Minat Beli Ulang lebih besar bila dibandingkan dengan pengaruh secara langsung variabel Brand Awareness terhadap loyalitas pelanggan, sehingga Brand Awareness berpengaruh signifikan terhadap Word of Mouth (WOM) melalui Minat Beli Ulang.

Hal ini dibuktikan dari perhitungan nilai pengaruh tidak langsung variabel Brand Awareness terhadap Word of Mouth (WOM) melalui Minat Beli Ulang yaitu sebesar 0,303 lebih besar jika dibandingkan dengan nilai pengaruh langsung variabel Brand Awareness terhadap Word of Mouth (WOM) sebesar $(0,095)$.

Penelitian ini sejalan dengan penelitian yang dilakukan oleh Katja Hutter,Julia Hautz,Severin Dennhardt dan Johann Füller (2013) yaitu The impact of user interaction in social media on brand awareness and purchase intention: the case of Mini on facebook. Dari penelitian ini dirumuskan bahwa Brand Awareness berpengaruh positif terhadap Minat Beli Ulang.

Pengaruh Brand Awareness terhadap Minat Beli Ulang Minat Beli Ulang juga didasarkan pada pengetahuan konsumen yang mereka peroleh dari media informasi mengenai merk tersebut dan yang diharapkan oleh konsumen adalah produk yang dibeli nya adalah merek yang sudah teruji kualitasnya dan dapat digunakan untuk memenuhi kedepan nya.

\section{Hipotesis 2: Diduga Brand Image berpengaruh signifikan terhadap Word of Mouth (WOM) melalui Minat Beli Ulang}

$\mathrm{H}_{0}$ : Brand Image tidak berpengaruh signifikan terhadap Word of Mouth (WOM) melalui Minat Beli Ulang

$\mathrm{H}_{1}$ : Brand Image berpengaruh signifikan terhadap Word of Mouth (WOM) melalui Minat Beli Ulang

Berdasarkan tabel 8 mengenai hasil analisis pengaruh langsung dan tidak langsung, maka dapat disimpulkan bahwa hipotesis $2\left(\mathrm{H}_{2}\right)$ dapat diterima karena kekuatan hubungan pengaruh secara tidak langsung Brand Image terhadap Word of Mouth (WOM) melalui Minat Beli Ulang lebih besar bila dibandingkan dengan pengaruh secara langsung variabel Brand Image terhadap loyalitas pelanggan, sehingga Brand Image berpengaruh signifikan terhadap Word of Mouth (WOM) melalui Minat Beli Ulang.

Hal ini dibuktikan dari perhitungan nilai pengaruh tidak langsung variabel Brand Image terhadap Word of Mouth (WOM) melalui Minat Beli Ulang yaitu sebesar 0,387 lebih besar jika dibandingkan dengan nilai pengaruh langsung variabel Brand Image terhadap Word of Mouth (WOM) sebesar $(0,005)$.

Hal ini didukung juga oleh penelitian Nulufi (2015) yang menyatakan bahwa Brand Image memiliki pengaruh positif dan signifikan terhadap keputusan pembelian yang dimediasi minat beli. Hal ini berarti jika brand image semakin baik maka minat beli dan pengambilan keputusan pembelian konsumen juga meningkat. Begitu juga sebaliknya jika brand image semakin rendah maka minat beli dan pengambilan keputusan pembelian juga akan menurun. Total pengaruh tidak langsung brand image terhadap keputusan pembelian melalui minat beli lebih besar dari pengaruh langsung brand image terhadap keputusan pembelian, sehingga minat beli dapat menjadi variabel mediasi.

\section{IV.Kesimpulan}

Berdasarkan hasil penelitian dan pembahasan mengenai "Analisis Pengaruh Brand Equity Untuk Meningkatkan Minat Beli Ulang Dan Word Of Mouth (Studi Kasus Batik Gonggong Tanjungpinang", maka dapat ditarik kesimpulan bahwa:

1. Brand Awareness berpengaruh signifikan terhadap Word of Mouth (WOM) melalui Minat Beli Ulang. Hal ini dibuktikan dari perhitungan nilai pengaruh tidak langsung variabel Brand Awareness terhadap Word of Mouth (WOM) melalui Minat Beli Ulang yaitu sebesar 0,303 lebih besar jika dibandingkan dengan nilai pengaruh langsung variabel Brand Awareness terhadap Word of Mouth (WOM) sebesar $(0,095)$. 
2. Brand Image berpengaruh signifikan terhadap Word of Mouth (WOM) melalui Minat Beli Ulang. Hal ini dibuktikan dari perhitungan nilai pengaruh tidak langsung variabel Brand Image terhadap Word of Mouth (WOM) melalui Minat Beli Ulang yaitu sebesar 0,387 lebih besar jika dibandingkan dengan nilai pengaruh langsung variabel Brand Image terhadap Word of Mouth (WOM) sebesar $(0,005)$.

3. Variabel Brand Awareness dengan nilai sig* 0,000 dan nilai $t_{\text {hitung }} 4,016$. Maka ini berarti bahwa Brand Awareness secara partial berpengaruh signifikan terhadap Minat Beli Ulang Batik gonggong Tanjungpinang

4. Variabel Brand Image dengan nilai sig* 0,000 dan nilai $t_{\text {hitung }}$ 3,181. Ini berarti bhwa Brand Image secara partial berpengaruh signifikan terhadap Minat Beli Ulang Batik gonggong Tanjungpinang

5. Variabel Brand Awareness dengan nilai sig* 0,002 dan nilai $t_{\text {hitung }} 3,235$. Ini berarti bahwa Brand Awareness secara partial berpengaruh signifikan terhadap Word Of Mouth

6. Variabel Brand Image dengan nilai sig 0,796 dan nilai $t_{\text {hitung }}$ 0,259. sehingga Brand Image secara partial tidak berpengaruh signifikan terhadap Word Of Mouth

7. Variabel Minat Beli Ulang Batik Gonggong dengan nilai sig 0,000 dan nilai $t_{\text {hitung }} 4,958$. Ini berarti bahwa Minat Beli Ulang Batik Gonggong secara partial berpengaruh signifikan terhadap Word Of Mouth

\section{Ucapan Terimakasih}

Artikel ini merupakan publikasi hasil penelitian dengan skema Penelitian Unggulan Perguruan Tinggi (PUPT) Tahun 2019 menggunakan dana yang bersumber dari Dana Internal Universitas Maritim Raja Ali Haji (UMRAH). Oleh karena itu penulis mengucapkan terimakasih kepada UMRAH atas dukungan pendanaannya demi kesuksesan penelitian ini.

\section{Daftar Pustaka}

Ali, Muhammad, 2010, Metodologi dan Aplikasi Riset Pendidikan, Bandung:Pustaka Cendikia Utama.

Christina, Ekel Valeriana, 2017, Pengaruh Brand Equity Terhadap Minat beli Produk Starbucks, Program Studi Manajemen, Universitas Sanata Dharma, Yokyakarta

Erida (2009), “Pengaruh Kepuasan Konsumen dan Insentif Terhadap Perilaku WOM (WORD OF MOUTH) Konsumen Jasa Angkutan Penumpang Bis Antar Kota Provinsi Kelas Eksekutif Di Bandung, Universitas Jambi, Jambi

Fadhila,Nida dan Harry Soesanto, 2016, Studi Tentang Social Media Marketing Dan Brand Awareness,Word of Mouth Terhadap Minat Beli Produk Mommilk (Studi Pada PenggunaInstagram,Mahasiswa

Universitas Diponegoro), Volume 5, Nomor 2, Tahun 2016, Halaman 1-9, http://ejournal-1.undip.ac.id/index.php/dbr ISSN (Online): 2337-3792

Ghozali, Imam, 2016, Aplikasi Analisis Multibariete Dengan Program IBM SPSS 23 (8 th Ed, Semarang: Badan Penerbit Universitas Diponegoro.

Hellier, P.K., Gearsen, G.M., Carr, R.A and Rickard, J.A (2003), Customer Repurchace Intention. A general Structural Equition Model" European Journal of Marketing, Vol 37 No. 11/12, pp 1762-1800

Keller, Kevin Lane, 2009, Startegic Brand Management (Building, Measure, and Managing Brand Equity), New Jersey: Prentice Hall , 2013, Manajemen Pemasaran Jilid $2\left(13^{\text {th }}\right.$ Ed), Jakarta:Erlangga 
Kumala, Octaviantika Benazir. 2012. Pengaruh Word of Mouth Terhadap Minat Beli Konsumen Pada Tune Hotels Kuta-Bali. Skripsi. Universitas Indonesia

Mahendrayasa, Andhanu Catur.,Srikandi Kumadji \&Yusri Abdillah. 2014. Pengaruh Word of Mouth terhadap Minat Beli serta Dampaknya pada Keputusan Pembelian. Fakultas Ilmu Administrasi. Universitas Brawijaya.

Molinari, L.K al, 2008, Satisfaction, Quality And ValueAnd Effect On repurchase And Positive Word Of mouth Behavioral Intentions In $A B 2 B$ Services Context, Journal of Services Marketing, Vol 22. No 5 pp 363-373

Rahma Nurvidiana Kadarisman Hidayat Yusri Abdillah, 2015, Pengaruh Word Of Mouth Terhadap Minat Beli Serta Dampaknya Pada Keputusan Pembelian (Survei Pada Konsumen Republica Cafe Malang Jalan Mt. Haryono Gg.XI Malang) Jurnal Administrasi Bisnis (JAB)|Vol. 22 No. 2 Mei 2015

Rizki, Annisa Noviana Puspa, 2018, Analisis Pengaruh Ekuitas Merek Terhadap Minat Pembelian Ulang Pada Layanan Navigatour Bukit Cimanggu City Bogor, Manajemen Fakultas Ekonomi Dan Manajemen Institut Pertanian Bogor.

Sugiono, 2014, Metode Penelitian Manajemen, Bandung:Alfabeta

Tjiptono, Fandy, 2014, Pemasaran Jasa, Penerbit Andi, Yokyakarta 